\title{
Reduction in Toxicity of Nano-Ag-Polyvinyl-pyrrolidone Using Hydra Proteins and Peptides during Zebrafish Embryogenesis
}

\author{
Soon Seok Kim, Jin Ah Lee and Min-Kyeong Yeo* \\ Department of Environmental Science and Engineering, College of Engineering, Kyung Hee University, \\ 1732 Deogyeong-daero, Giheung-gu, Yongin-si, Gyeonggi-do, Seoul 17104, Korea \\ * Correspondence: bioclass@khu.ac.kr; Tel.: +82-031-201-2413
}

Received: 24 July 2019; Accepted: 23 August 2019; Published: 27 August 2019

\begin{abstract}
Hydra magnipapillata cells reduce the toxicity of silver nanomaterials to zebrafish (Danio rerio) embryos. In this study, we investigated whether Hydra protein (HP) and Hydra basal disc peptide (Hym176) materials reduce nano-Ag-polyvinylpyrrolidone (N-Ag-PVP) toxicity during embryogenesis of the nanosensitive organism zebrafish. Protein (HP) was extracted from Hydra, and peptide (Hym176) was extracted from the hydra basal disc, which is attractive to nanomaterials and related to the immune system. The experimental conditions were exposure to N-Ag-PVP, HP, $\mathrm{N}-\mathrm{Ag}-\mathrm{PVP}+\mathrm{HP}, \mathrm{Hym} 176$, or N-Ag-PVP+Hym176 during embryo development. N-Ag-PVP+HP group showed lower toxicity than N-Ag-PVP group. In addition, in the N-Ag-PVP+HP group formed aggregated nanomaterials ( $\geq 200 \mathrm{~nm}$ size) through electrostatic bonding. In the gene expression profile, HP group differed in gene expression profile compared the other experimental groups and it was no genetic toxicity. HP showed a tendency to reduce side effects and abnormal gene expression produced by N-Ag-PVP with no evidence of inherent toxicity. Considering the potential nanotoxicity effects of released nanomaterials on the ecosystem, the reduction of nanotoxicity observed with HP natural materials should be regarded with great interest in terms of the overall health of the ecosystem.
\end{abstract}

Keywords: nanotoxicity; nano-Ag-polyvinylpyrrolidone; Hydra protein; Hydra peptide; reduced toxicity; microarray

\section{Introduction}

The chemical composition, morphology, density, and physicochemical properties of nanomaterials differ from those of conventional bulk materials [1]. Among the commercially available nanomaterials, silver nanomaterials exhibit high antimicrobial activity [2], are incorporated into antimicrobial plastics, fabrics [3], fibers [4], food supplements, and packing [5], and are used as water disinfectants and to improve wound healing [6]. However, many studies have also reported toxicity caused by silver nanomaterials, including cellular DNA damage, protein oxidation, production of reactive oxygen species (ROS), and induction of cell damage and death [2]. The toxicity of silver nanomaterials was previously reported in a study in which zebrafish embryos were exposed to treated water $[7,8]$.

Owing to their widespread use, silver nanomaterials are now dispersed throughout the environment, and both humans and ecological organisms are widely exposed to them $[9,10]$. Therefore, there is an increasing need to investigate the ecotoxicity of silver nanomaterials and manage those risks within a regulatory framework for use of silver nanomaterials [11]. Nanomaterials directly introduced into rivers can endanger the ecosystem and human health [12], nanomaterials that have not been removed during wastewater treatment may enter and affect river ecosystems [13,14]. Degradation of nanomaterials after use is necessary to prevent their release into ecosystems. However, chemical-based 
destruction can cause the release of secondary pollutants such as trihalomethanes (THM) [15]. Therefore, there is a need for treatment methods that use bio-based natural substances.

In our previous study, exposure to $100 \mathrm{mg} / \mathrm{L}$ of silver nanocolloids produced limited toxicity in Hydra magnipapillata, which showed $100 \%$ regeneration after 7 days [8]. When zebrafish were exposed to Hydra cells mixed with silver nanocolloids and nanotubes, the hatching percentage increased, the abnormality percentage decreased, and the expression of apoptosis-related genes was reduced compared to embryos exposed only to the silver nanocolloids and nanotubes [16]. The silver concentrations used in the Hydra cell co-exposure study were 50,000-100,000-fold greater than the concentrations that decreased the hatching percentage and induced abnormalities in zebrafish exposed to nanosilver alone (nanosilver $20 \mathrm{ng} / \mathrm{L}$ and silver ions $10 \mathrm{ng} / \mathrm{L}$ ) [17]. However, the survival and regeneration percentages of the exposed Hydra and the shape and size of the agglomerated nanomaterials in the basal disk of Hydra were changed after exposure to nanosilver. Unlike vertebrates, Hydra, a Cnidarian, has only an innate immune system. The Hydra basal disc is associated with defense and immune functions and contains the bulk of the antimicrobial peptides (AMP) the organism uses to defend against external bacterial attacks [18]. The role of the basal disc in defense against nanomaterial exposure therefore needs to be investigated [19-21]. Hym176 is one of neuropeptides on epithelial cells and neuropeptides of Hydra were found to have indeed antimicrobial activity [21]. Silver nanomaterials were aggregated at the Hydra basal disc [8] that consists of Hym176 neuropeptides.

In this study, we based on the results of a previous study in which Hydra were not affected by the toxicity of nanomaterials [8], and we used Hydra protein (HP) and Hydra basal disc peptide (Hym176) preparations as biobased substances to reduce the toxicity of N-Ag-PVP. The physicochemical properties of nano-Ag-polyvinylpyrrolidone (N-Ag-PVP) were analyzed in two types of biomaterial (HP, Hym176)-containing environments.

Zebrafish embryos were then co-exposed to the nanosilver and/or Hydra preparations to test their cytotoxicity. The percentages of abnormal hatched larvae and larval morphology were assessed $72 \mathrm{~h}$ post-fertilization (hpf). Gene expression levels in the hatched larvae were confirmed by mRNA-seq analysis and quantified using quantitative real-time polymerase chain reaction (qRT-PCR).

\section{Materials and Methods}

\subsection{Preparation of $N-A g-P V P, H P$, and Hym176}

N-Ag-PVP was purchased from Avention Co. (Seoul, Korea). The N-Ag-PVP powder was mixed with distilled water and dispersed using an ultrasonic generator (Power Sonic 405, Hwashin Tech, Seoul, Korea) for $40 \mathrm{~min}$ at $19 \pm 1{ }^{\circ} \mathrm{C}$ to prepare a stock solution, which was then diluted with dechlorinated tap water to yield a final concentration of $1 \mathrm{mg} / \mathrm{L}$. Immediately before exposure, the solution was dispersed again for $40 \mathrm{~min}$ using an ultrasonic generator.

Hydra protein was extracted using TRIzol ${ }^{\mathrm{TM}}$ (Invitrogen Co., Wilmington, DE, USA) with some modifications. Using $100 \mathrm{mg}$ of Hydra which had been pulverized, then $200 \mu \mathrm{L}$ of Red Orange was fractionated. Final step, the HP stored in distilled water at $4{ }^{\circ} \mathrm{C}$, and used for experiments within $24 \mathrm{~h}$. Distilled water was removed, the HP was crushed with a homogenizer. Dechlorinated tap water was added to the crushed HP to yield a final concentration of $4 \mathrm{mg} / \mathrm{L}$, which was then dispersed using an ultrasonic generator at $19 \pm 1{ }^{\circ} \mathrm{C}$ for $80 \mathrm{~min}$.

The Hydra peptide Hym176 (H-Ala-Pro-Phe-Ile-Phe-Pro-Gly-Pro-Lys-Val-NH ${ }_{2}$ ) was synthesized using the method proposed by Fujisawa [22] with some modifications. First, $0.637 \mathrm{~g}$ of rink amide AM resin was dissolved in dichloromethane (DCM) and allowed to swell for $30 \mathrm{~min}$. The resin was then mixed with deprotected fluorenylmethyloxycarbonyl (Fmoc) for $10 \mathrm{~min}$ and washed with $20 \%$ piperidine/dimethylformamide (DMF). Resin coupling was carried out at $22 \pm 1{ }^{\circ} \mathrm{C}$ for $40 \mathrm{~min}$, and then $0.2 \mathrm{mmoL}$ Fmoc-Val-OH, $0.2 \mathrm{mmoL}$ 2-(1H-benzotriazole-1-yl)-1,1,3,3-tetramethylammonium tetra-fluoroborate (TBTU), and $0.2 \mathrm{mmoL} N, \mathrm{~N}$-diisopropylethylamine (DIEA) were added to the resin. After coupling, the resin was washed one or two times with DMF. This process was repeated until all 
the amino acids were continuously coupled to the chain, extending the length of the peptide. When the final amino acid was coupled to the chain, the de-protected Fmoc-treated peptide was washed three times with methanol and then dried. The dried resin was added, and an appropriate amount of cleavage solution was added before incubation $\left(40^{\circ} \mathrm{C}, 3.5 \mathrm{~h}\right)$. The solution was filtered, ether was added to the precipitate, and centrifugation $(1006.2 \mathrm{~g}, 2 \mathrm{~min})$ was performed twice. The synthesized Hym 176 was dried for several minutes, lyophilized, and then stored at $-20^{\circ} \mathrm{C}$. The lyophilized Hym 176 was dissolved completely in $1 \mathrm{~mL}$ of distilled water, diluted with $4 \mathrm{mg} / \mathrm{L}$ of dechlorinated tap water, and then dispersed using an ultrasonic generator at $19 \pm 1{ }^{\circ} \mathrm{C}$ for $80 \mathrm{~min}$.

\subsection{Physicochemical Properties of $N-A g-P V P$ and $N-A g-P V P+H P$}

Field emission scanning electron microscopy (FE-SEM, LEO SUPRA 55, Carl Zeiss, Oberkochen, Germany; $10 \mathrm{kV}$ ) was used to assess the surface morphology of N-Ag-PVP and N-Ag-PVP+HP (Figure S1A). The crystallinity of N-Ag-PVP and N-Ag-PVP+HP was analyzed using an X-ray diffractometer (XRD, model PW 1830, Philips, Amsterdam, The Netherlands; 40 mA, 40 kV, 3-90, $6 \mathrm{deg} / \mathrm{min})$. A nickel filter and $\mathrm{CuK}$ radiation $(30 \mathrm{kV}, 30 \mathrm{~mA})$ were used, and the analyses were performed within a $2 \theta$ range of $5-80^{\circ}$ at a scan rate of $10^{\circ} / \mathrm{min}$ (Figure S1B). The material distribution characteristics and zeta-potential were measured using a particle size analyzer (ELS-Z2, Tokyo, Japan). Analytical samples were diluted with distilled water. The physical conditions were as follows: water temperature $25^{\circ} \mathrm{C}$, refractive index 1.3328 , and viscosity 0.8878 centipoise (cP).

\subsection{Experimental Animals}

The zebrafish (Danio rerio, wild type) used in this study were grown in our laboratory to 7-8 months of age. The zebrafish were reared according to the method proposed by Westerfield [23], using the following conditions: water temperature $28 \pm 1{ }^{\circ} \mathrm{C}$; light/dark photoperiod $14 / 10 \mathrm{~h}$; $\mathrm{pH} 7.1 \pm 0.5$; chlorine concentration $0.8 \mathrm{mg} / \mathrm{L}$; ionic strength $2.2 \times 10^{5}$; and total organic carbon (TOC) concentration $0.9 \mathrm{mg} / \mathrm{L}$. The fish were fed brine shrimp (Artemia sp.), bloodworms, and dry flake feed (TetraMin, Melle, Germany) three times a day.

The Hydra were obtained from the Korea Ocean Research and Development Institute (KORDI, Geoje, Korea). The Hydra were incubated in $0.5 \mathrm{~L}$ of $\mathrm{Hydra}$ culture medium at a water temperature

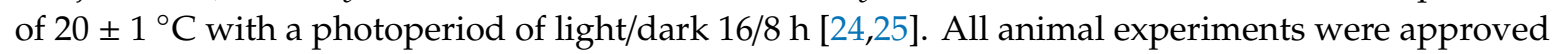
by the Institutional Animal Care and Use Committee (IACUC) of Kyung Hee University and were conducted according to the provisions of the IACUC.

\subsection{Exposure Conditions}

The N-Ag-PVP, HP, and Hym176 preparations were dispersed immediately before exposure. The N-Ag-PVP+HP and N-Ag-PVP+Hym176 were dispersed independently using an ultrasonic generator for $40 \mathrm{~min}$, mixed, and dispersed for an additional $40 \mathrm{~min}$.

The collected embryos were washed with dechlorinated tap water at $20.5{ }^{\circ} \mathrm{C}$, after which 20 embryos were allocated to each well of 6-well plates. In the experimental groups, 60 embryos were exposed to N-Ag-PVP (1 mg/L), HP (4 mg/L), N-Ag-PVP+HP (1 or 4 mg/L), Hym176 (4 mg/L), or N-Ag-PVP+Hym176 (1 or $4 \mathrm{mg} / \mathrm{L})$. The $4 \mathrm{mg} / \mathrm{L} \mathrm{HP}$ concentration was chosen based on the results of prior range-finding experiments. All experimental groups were exposed simultaneously for $1 \mathrm{hpf}$ to ensure the same embryonic stage across treatments. Subsequently, the embryos were observed using a stereoscopic microscope (SZ61, Olympus, Tokyo, Japan) at 4, 12, 24, 32, and $48 \mathrm{~h}$ after exposure [16,17]. Embryonic staging was carried out according to the standardized staging series established by Kimmel et al. [26]. The exposed embryos were maintained at $28 \pm 1{ }^{\circ} \mathrm{C}$ in an incubator. Dead embryos were removed to avoid contamination of the test solution. After $72 \mathrm{~h}$ of exposure, embryos that did not hatch were classified as dead, and the hatching percentage, abnormality percentage, and morphological abnormality percentage of viable larvae were assessed. The experiment was repeated three times, and the values are expressed as mean \pm standard deviation (SD). 


\subsection{Microarray Analysis}

Total RNA was isolated from the hatched zebrafish larvae (72 hpf, whole body exposure) using TRIzol $^{\mathrm{TM}}$ (Thermo Fisher Scientific, Wilmington, DE, USA ). The quality of the RNA was assessed with an Agilent 2100 bioanalyzer (Agilent Tech., Waldbromm, Germany) using an RNA 6000 Nano Chip (Agilent Technologies, Amstelveen, The Netherlands). The RNA was quantified using an ND-2000 spectrophotometer (Thermo Fisher Scientific, Wilmington, DE, USA ) and confirmed to have an absorbance ratio $>1.8$ and integrity $>7.0$.

The SENSE mRNA-Seq library preparation kit (Lexogen, Inc., Vienna, Austria) was used for mRNA sequencing and library construction. High-throughput sequencing was performed using a HiSeq 2000 (Illumina, Inc., San Diego, CA, USA). The library was prepared from a $2 \mu \mathrm{g}$ sample of total RNA using the SMARTer Stranded RNA-Seq Kit (Takara Bio, CA, USA). Separation of mRNA was performed using a Poly (A) RNA selection kit (LEXOGEN, Inc., Vienna, Austria). Isolated mRNA was synthesized into cDNA and sheared according to the manufacturer's instructions. Indexing was performed using Illumina index 1-12. Polymerase chain reaction was used for amplification. The library was identified using the Agilent 2100 bioanalyzer (DNA High Sensitivity Kit), and the average fragment size was assessed. Quantification was performed using (Thermo Fisher Scientific, Wilmington, DE, USA) and a library quantification kit. High-throughput sequencing was performed with 100-bp paired-end sequencing using a HiSeq 2500 (Illumina, Inc.).

To read the mRNA-seq, mapping was performed using TopHat to obtain sorted files. Differentially expressed genes (DEG) were determined based on the coefficients of inherent and multiple alignments using bedtooLs. The read count data were processed based on the quantile normalization method, using EdgeR in R ( $R$ development Core Team, 2016) and Bioconductor. The sorted files were also used to combine copies, estimate abundances, and detect DEG or isoforms using Cufflinks. Fragments per kilobase of exon per million fragments (FPKM) were used to determine the expression levels of the genes.

Up- or down-regulated genes were identified using ExDEGA v1.2.1.0 (EBIOGEN, Inc., Seoul, Korea). Categorization of the genes was based on a search performed using DAVID (http://david. abcc.ncifcrf.gov). In each experimental group, FPKM gene expression level was converted to a log2 value, and the relative level with respect to the control group is presented. Approximately 3000 genes selected from the DEG analysis were analyzed by DAVID. The Gene Ontology (GO) from the DAVID analysis was used to show the correlation in Quick GO (https://www.ebi.ac.uk/QuickGO). The genes involved in tight junctions, forkhead box $\mathrm{O}$ (FOXO) and mitogen-activated protein kinase (MAPK) signaling pathways, and G protein-coupled receptors (GPCRs), which affect the embryonic development stage in the KEGG pathway (https://www.genome.jp/kegg/pathway.html), were identified. The clustering heatmap profiles of DEGs were compared across the experimental groups using the Multiple Experiment Viewer software program v4.9 (MeV). The average fold-change (FC) for each gene was expressed as a standardized $z$-score.

\section{6. qRT-PCR Analysis}

Table 1 summarizes the primer information for the seven major genes (cldna, cdc42l, igf1, zgc:55558, mapk10, mapk11, and tp53) in the signaling pathway of the cells used for qRT-PCR and that of the reference gene (actb2). Claudin is a key component of tight junctions and maintains intercellular junctions, while some claudin gene defects have been reported to cause hearing loss [27]. Cdc421 is a Ras-related GTP-binding protein that is required for angiogenesis by regulating the filament-actin (F-actin) of filopodia [28]. In the MAPK signaling pathway, Igf1 plays an important role in embryonic growth and development [29]. zgc:55558 (Ras), mapk10 (JNK), mapk11 (ERK), and tp53 (p53) are located in the main pathway that receives extracellular signals from growth factors and integrates signals, thus promoting cell growth and proliferation [16].

Reverse transcription was performed using $3 \mu \mathrm{g}$ of total RNA and SuperScript II RTase (Invitrogen, Carlsbad, USA). qRT-PCR was performed in a SuperScriptTM real-time PCR system (Applied 
Biosystems, Waltham, USA) using a SYBR green PCR kit (Applied Biosystems). The qRT-PCR cycle conditions were as follows: pre-denaturation at $95^{\circ} \mathrm{C}$ for $10 \mathrm{~min}$, followed by 40 cycles of $95{ }^{\circ} \mathrm{C}$ for $15 \mathrm{~s}$ and $59^{\circ} \mathrm{C}$ for $30 \mathrm{~s}$. Data were analyzed using StepOne ${ }^{\mathrm{TM}}$ software v2.2.2 (Applied Biosystems). The mRNA expression levels for the seven genes were normalized to that of the reference gene and quantified using the $2^{-\Delta \Delta C t}$ method. Amplification plots and melting curves were obtained for the amplified products.

Table 1. Primer of key genes involved in the signaling pathway selected for qRT-PCR.

\begin{tabular}{|c|c|c|c|c|}
\hline Gene Name & Gene Symbol & Function & Accession No. & Primer Sequences $\left(5^{\prime} \rightarrow 3^{\prime}\right)$ \\
\hline claudin a & cldna & structural molecule activity & $\begin{array}{c}\text { NM } \\
-131762\end{array}$ & $\begin{array}{l}\text { (F) TGTGGCAAGTCACTGCTTTT } \\
\text { (R) CACGCAACTCATCCAAATTC }\end{array}$ \\
\hline $\begin{array}{l}\text { cell division cycle } \\
42, \text { like }\end{array}$ & cdc421 & $\begin{array}{l}\text { GTP binding, GTPase activity, } \\
\text { nucleotide binding, protein kinase } \\
\text { binding }\end{array}$ & $\begin{array}{c}\text { NM } \\
-199865\end{array}$ & $\begin{array}{l}\text { (F) GGCAGGAAGACTACGACAGA } \\
\text { (R) GGAGGAAGGAGAAACAACTGA }\end{array}$ \\
\hline $\begin{array}{l}\text { insulin-like growth } \\
\text { factor } 1\end{array}$ & igf1 & $\begin{array}{l}\text { Growth factor activity, hormone } \\
\text { activity, insulin-like growth factor } \\
\text { receptor binding }\end{array}$ & $\begin{array}{c}\text { NM } \\
-131825\end{array}$ & $\begin{array}{l}\text { (F) GTGGACGAATGCTGCTTTCA } \\
\text { (R) CTGTCTTCACAGGCGCACAA }\end{array}$ \\
\hline zgc:55558 & zgc:55558 & $\begin{array}{l}\text { GTP binding, GTPase activity, } \\
\text { nucleotide binding, }\end{array}$ & $\begin{array}{c}\text { NM } \\
200258\end{array}$ & $\begin{array}{l}\text { (F) TTTTTACACCCCCATCCTTT } \\
\text { (R) GGTCTCGTGTGCACAGACAT }\end{array}$ \\
\hline $\begin{array}{l}\text { mitogen-activated } \\
\text { protein kinase } 10\end{array}$ & mapk10 & $\begin{array}{l}\text { ATP binding, JUN kinase activity, } \\
\text { MAP kinase activity, kinase activity, } \\
\text { nucleotide binding, protein kinase } \\
\text { activity, protein serine/threonine } \\
\text { kinase activity, transferase activity }\end{array}$ & $\begin{array}{c}\text { NM } \\
\_001037701\end{array}$ & $\begin{array}{l}\text { (F) TCGAGGAGAGAACAAAGAATGG } \\
\text { (R) AGGCTCTCGCTGCTGTTCAC }\end{array}$ \\
\hline $\begin{array}{l}\text { mitogen-activated } \\
\text { protein kinase } 11\end{array}$ & mapk11 & $\begin{array}{l}\text { ATP binding, MAP kinase activity, } \\
\text { kinase activity, nucleotide binding, } \\
\text { protein kinase activity, protein } \\
\text { serine/threonine kinase activity, } \\
\text { transferase activity }\end{array}$ & $\begin{array}{c}\text { NM } \\
\_001002095\end{array}$ & $\begin{array}{l}\text { (F) CAGTACTGCCCTCTCCTTCTT } \\
\text { (R) ATCGTCTCGTCTGGCTGAAC }\end{array}$ \\
\hline tumor protein $\mathrm{p} 53$ & tp53 & $\begin{array}{l}\text { DNA binding, DNA-binding } \\
\text { transcription factor activity, metal } \\
\text { ion binding, promoter-specific } \\
\text { chromatin binding, protein binding, } \\
\text { sequence-specific DNA binding, } \\
\text { transcription regulatory region } \\
\text { DNA binding, }\end{array}$ & $\begin{array}{c}\text { NM } \\
-001271820\end{array}$ & $\begin{array}{l}\text { (F) TGCGATACATGTGATCCATT } \\
\text { (R) CAGTGTCCAGCAACAAAGGT }\end{array}$ \\
\hline actin, beta 2 & actb2 & ATP binding, nucleotide binding & $\begin{array}{c}\mathrm{NM} \\
181601\end{array}$ & $\begin{array}{l}\text { (F) GACTCAAACTGCGCAGAGAA } \\
\text { (R) AGTCAAGCGCCAAAAATAAC }\end{array}$ \\
\hline
\end{tabular}

\subsection{Statistical Analysis}

Statistical analyses were performed using IBM's Statistical Package for the Social Sciences (SPSS) v23.0 (IBM, Armonk, New York, USA). Analysis of variance (ANOVA) was performed to compare and evaluate the experimental groups, followed by Tukey's post-hoc test for multiple comparisons. Values were considered statistically significant at $p$-values $<0.05$ and $<0.01$.

\section{Results and Discussion}

\subsection{Properties of N-Ag-PVP and HP}

Low organic matter is favorable to NP aggregation in water [30]; thus, all AgNPs particle sizes at $1 \mathrm{~h}$ exposures for analysis in distilled water were increased (Table 2). The particle size of N-Ag-PVP (30 nm to $285.50 \mathrm{~nm}$ ) at $1 \mathrm{~h}$ was increased by 9 fold more than those on original particle (Figure S1A). In addition, the changes of N-Ag-PVP+HP particle distributions were twice $(534.4 \mathrm{~nm})$ than N-Ag-PVP $(285.50 \mathrm{~nm})$ because HP seemed to increase aggregation. The nanomaterials were found to have 22.84 (N-Ag-PVP) and 5.54 (N-Ag-PVP+HP) mv of negative charge on the surface. (Table 2). The nanomaterials could have a high affinity for the positively charged molecules in an organism [30], but Hydra protein could cause low affinity because it changes the surface charge. 
Table 2. Analyses of zeta potential and DLS changes of N-Ag-PVP and N-Ag-PVP + HP.

\begin{tabular}{ccc}
\hline & N-Ag-PVP & N-Ag-PVP+HP \\
\hline Zeta potential $(\mathrm{mV})$ & $-22.84 \pm 0.16$ & $-5.54 \pm 0.80$ \\
Diameter $(\mathrm{nm})$ & $285.50 \pm 16.40$ & $534.40 \pm 122.05$ \\
\hline
\end{tabular}

The XRD patterns of N-Ag-PVP and N-Ag-PVP+HP were not different, but the sensitivity with HP was lower. HP did not affect the crystallographic planes of Ag-PVP (Figure S1B). N-Ag-PVP showed peaks at $38^{\circ}, 44.18^{\circ}, 64.39^{\circ}$, and $77.32^{\circ}$, while N-Ag-PVP+HP showed peaks at $38.16^{\circ}, 44.34^{\circ}$, $64.48^{\circ}$, and $77.44^{\circ}$, the characteristic peaks of Ag-PVP [31].

HR-Raman analysis showed different positions of major bands for N-Ag-PVP and HP (Figure S1C). The major band positions in HP were 563, 785, 955, and $1089 \mathrm{~cm}^{-1}$. For both the N-Ag-PVP and $\mathrm{N}-\mathrm{Ag}-\mathrm{PVP}+\mathrm{HP}$ aggregates, the $236 \mathrm{~cm}^{-1}$ and $222 \mathrm{~cm}^{-1}$ bands appeared to be due to the Ag-O bonds [32] . Additionally, the $\mathrm{C}=\mathrm{O}$ and $\mathrm{CH}_{2}$ bonds of PVP indicated interaction between PVP and Ag NPs. Analysis of the N-Ag-PVP sample indicated that the $1601 \mathrm{~cm}^{-1}$ and $2933 \mathrm{~cm}^{-1}$ bands corresponded with $\mathrm{C}=\mathrm{O}$ and $\mathrm{CH}_{2}$ bonds, respectively, while the $\mathrm{C}=\mathrm{O}$ and $\mathrm{CH}_{2}$ bonds corresponded with the $1605 \mathrm{~cm}^{-1}$ and $2918 \mathrm{~cm}^{-1}$ bands, respectively, for the N-Ag-PVP+HP sample [33].

PVP-coated silver nanoparticles can become stably dispersed in fresh water and may remain dispersed over a wide range of $\mathrm{pH}$ values [34]. However, part of the dispersant in the environmental medium can be detached and flocculate or precipitate as a result of displacement by other molecules such as inorganic ions $[35,36]$.

The toxicity of silver nanomaterials is known to be associated with release of silver ions dispersants [37]. Silver ions $\left(\mathrm{Ag}^{+}\right)$are toxic due to their strong affinity for thiol and disulfide groups [9]. Of note, PVP-coated silver nanomaterials have been reported to release $48 \%$ of their silver ions after $120 \mathrm{~h}$ in fresh water [38].

\subsection{Effects of HP and Hym176 on N-Ag-PVP-Exposed Zebrafish Embryos}

Approximately $10 \mathrm{~min}$ after HP- and N-Ag-PVP+HP-exposure on embryo (1.5 hpf), HP was adsorbed onto the chorion surrounding the embryo (Figure S2c,d). Aggregates, which were not observed in the N-Ag-PVP- and Hym176-exposed groups (Figure S2e), were formed and adsorbed onto the chorion in the N-Ag-PVP+Hym176-exposed group (Figure S2f).

The results of the zebrafish embryo exposures are presented as hatching percentages, abnormality percentages, and morphological abnormality percentages. Significance was assessed using a homogeneous subset of post-hoc test results. The hatching percentage of the N-Ag-PVP-exposed group was $41.7 \pm 2.9 \%$, which was significantly lower than that of the control group $(78.3 \pm 0.4 \%$; $p<0.01$; Figure 1a). The hatching percentages of the HP- and N-Ag-PVP-HP-exposed groups were similar to that of the control group. On the other hand, the abnormality percentages of the N-Ag-PVPand N-Ag-PVP+Hym176-exposed groups significantly increased to 4.0- and 3.53-fold greater that of the control group, respectively $(p<0.01)$. In N-Ag-PVP-exposed embryos, tail morphogenesis was abnormal in $36 \%$ of the hatched larvae $(p<0.01$; Figure 1b). Overall, the N-Ag-PVP- and $\mathrm{N}-\mathrm{Ag}$-PVP+Hym176-exposed groups had abnormal tails and edema. 

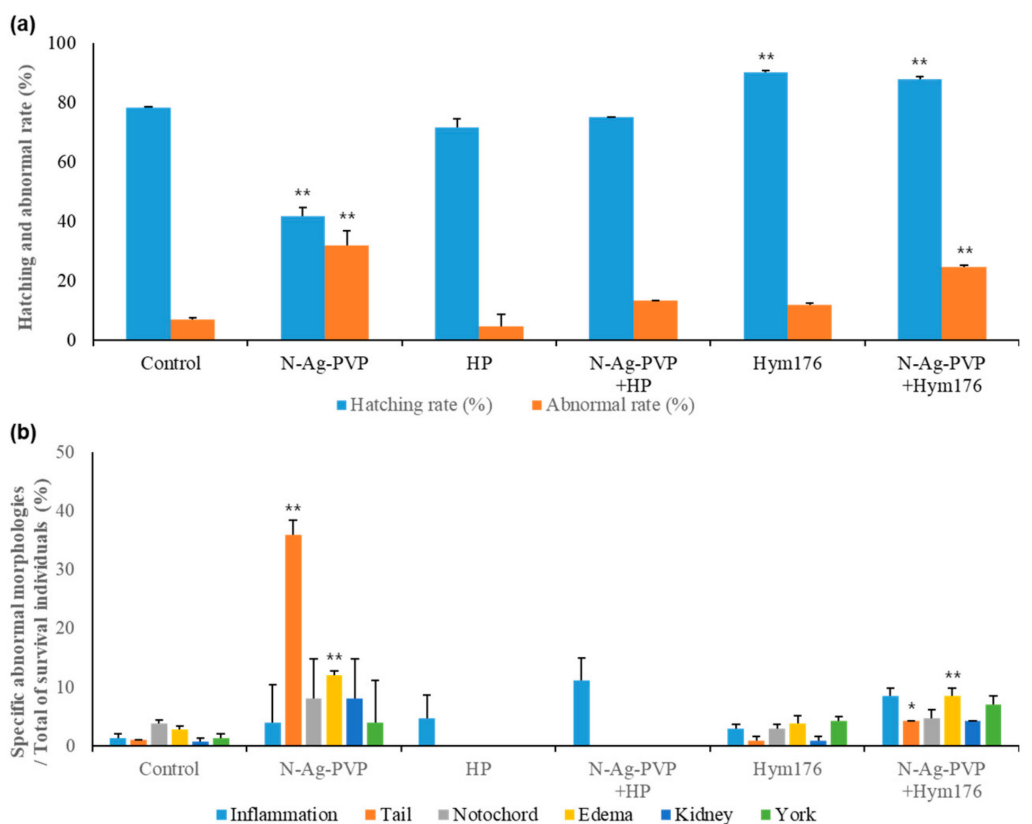

Figure 1. The effects of N-Ag-PVP, HP, N-Ag-PVP+HP, Hym176, and N-Ag-PVP+Hym176 on the hatching and abnormal rate (a) and rates of specific abnormal morphologies among surviving embryos (b). All measurements are reported as the group mean of three replicates and the standard deviation $(\mathrm{n}=60)$. ${ }^{*}$ comparison of experimental groups to a homogeneous subset of post-hoc test results $(p<0.05),{ }^{* *}$ comparison of experimental groups to a homogeneous subset of post-hoc test results $(p<0.01)$.

Complex abnormalities were observed in larvae exposed to N-Ag-PVP. Edema of the heart and yolk sac, curved notochord loss, inflammation of the tail and fins, and abnormal kidney morphology were observed (Figure S3b). Fin inflammation was observed in the HP- and N-Ag-PVP+HP-exposed groups (Figure S3c,d). In the Hym176-exposed group, complex abnormalities (inflammation, edema of the head, heart and yolk sac, abnormal kidney morphology and bleeding, and curved notochord) were identified (Figure S3e). Lastly, edema and a cracked yolk sac surface, inflammation, kidney morphological deformities, and a curved notochord were evident in the N-Ag-PVP+Hym176-exposed group (Figure S3f). Overall, the Hym176- and N-Ag-PVP+Hym176-exposed groups showed abnormalities such as inflammation of the embryo, curved notochord, and edema in major organs, similar to the N-Ag-PVP-exposed group.

The toxicity of silver nanomaterials in the embryo is likely related to their adsorption onto the cell membrane [38]. The aggregates of N-Ag-PVP and HP were greater than $200 \mathrm{~nm}$ in size and could not easily pass through the chorion pore canals (CPCs), thereby reducing the effects of N-Ag-PVP exposure on zebrafish embryos [39]. When present within the chorion (thickness $=3.5 \mu \mathrm{m}, \mathrm{CPC}$ diameter $=$ $0.5-0.7 \mu \mathrm{m}$, and pore spacing $=1.5-2.5 \mu \mathrm{m}$ ) and around the embryo, nanoparticles $\leq 100 \mathrm{~nm}$ in size may penetrate the CPCs in a concentration-dependent manner, increasing internal exposure and consequent toxicity to the embryo [40]. As the aggregates formed between N-Ag-PVP and Hym176 (30 base pair (bp), 11-12 nm) were relatively small compared with the HP aggregates, they are likely to penetrate directly through CPCs. The absorption of nanomaterials by endocytosis is more a function of particle size than of chemical properties, with a $100 \mathrm{~nm}$ upper limit for effective absorption through the cell membrane. Silver nanomaterials may be adsorbed onto the cell membrane, subsequently reaching the nucleus by endocytosis [41].

We postulated that HP and Hym176 may bind to and consequently reduce the toxicity of silver nanomaterials dispersed in water. In our pre-experiments, we found that the toxicity of N-Ag-PVP $(1 \mathrm{mg} / \mathrm{L})$ was reduced by co-incubation with $\mathrm{HP}(2,4$, or $6 \mathrm{mg} / \mathrm{L})$ in a concentration-dependent manner. This result is similar to previous results indicating that the Ag ion of Ag NP is bound by natural organic 
matter, such as humic acid, in natural waters [42]. In many commonly used test organisms, exposure to nanomaterials produces adverse effects on the immune system, such as apoptosis, but Hydra appear to be less sensitive to immune toxicity [8]. We have investigated the possibility of several hydra peptides (Hym323, Hym330, Hym346) that constitute the basal site in consideration of the resistance and regeneration response of Hydra to nanomaterial toxicity [20]. The peptide Hym176 was not difference to the hatching rate of embryos after mixing with $\mathrm{N}$-Ag-PVP but the abnormal rate was increased on $\mathrm{N}-\mathrm{Ag}$-PVP+Hym176 exposed group. However, the hatching rates of Hym176 and N-Ag-PVP+Hym176 exposed groups were over $80 \%$ (Figure 1 ). These result based with the Hydra basal disc is associated with defense and immune functions [21] and Hydra basal disc peptide (Hym176) probably defense against nanomaterial exposure. However, there were abnormal phenotypes (edema, tail abnormal) on Hym176 and N-Ag-PVP+Hym176 exposed groups (Figure 1, Figure S2e,f).

There are two possible explanations for the toxic effects of the Hydra peptides. The first is the size of Hym176 (30 bp, 11-12 nm), and the second is the effect of the amide functional group at the Hym176 sequence end. It is speculated that aggregates formed between N-Ag-PVP and Hym176 are more likely to penetrate directly through CPCs because they are relatively small compared to aggregated N-Ag-PVP and HP.

However, the peptides consisting only of amino acids did not affect the hatching percentage of the embryos before or after mixing with N-Ag-PVP. The amino group $\left(\mathrm{NH}_{2}{ }^{+}\right)$at the terminal end of Hym176 appeared to be the main binding site for N-Ag-PVP. To reduce the concentration and toxicity of silver nanomaterials in water, it is worth considering the use of organic matter or a substance with a functional group that can induce dislocation.

\subsection{Microarray and qRT-PCR Analyses}

The clustering heatmap profile of DEGs for 10,308 genes in the exposed embryos of each experimental group after mRNA sequence analyses was expressed as a z-score that standardized each average FC value using the MeV program (Figure S4). The mRNA sequence analysis was carried out based on the 14,474 zebrafish (danRer10) genes registered in the University of California Santa Cruz (UCSC) Genome Browser database. The DEG analyses using the ExDEGA program examined a number of genes with FC value $\geq 2$ and $\leq 0.5$ and normalized $R C(\log 2)$ value $\geq 10$. All treatment groups had more down-regulated than up-regulated genes. Among these comparisons of DEGS, HP vs. control had 2686 up- or down-regulated genes, while N-Ag-PVP+HP vs. HP had the greatest difference in number of differentially expressed genes (2879 genes).

The effects of the various treatments on gene expression were determined using Venn diagrams. The HP treatment had an independent effect on 861/1238 genes, the highest among all experimental groups, not while but 33/28/89 (up/contra/down-regulated gene number) genes were affected solely by HP (Figure 2a). In the Hym176-exposed group, the expression of 198/0/178 genes was altered (Figure 2b). Moreover, N-Ag-PVP, HP, or Hym176, when added independently to embryo cultures, affected 26/113/149 genes, respectively (Figure 2c). In the N-Ag-PVP-exposed group, the expression of 169/2/281 genes was altered (Figure 2d). On the other hand, in the four experimental groups, with the exception of N-Ag-PVP, the numbers of genes that showed FC (up/contra/down-regulated gene number) were 35/67/151, which may significantly affect embryogenesis (Figure 2e). However, the presence of 67 contra-regulated genes was likely to have caused errors in the analysis. The contra-regulated gene conflicts with the results of the experimental group but could be an indicator of the tendency for the N-Ag-PVP, HP, and Hym176 exposure groups to effect one other. 

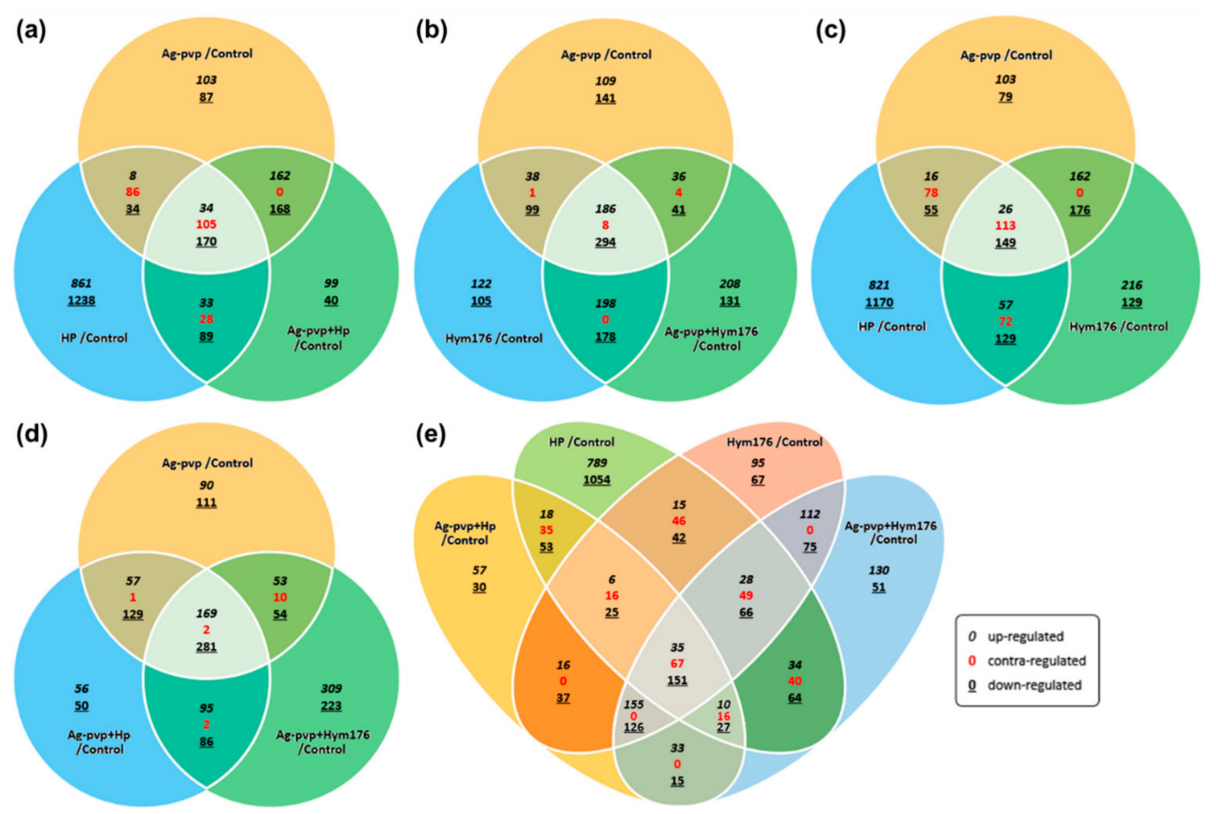

Figure 2. Venn diagrams illustrating the gene expression patterns in each experimental group; contra-regulated means that the effects on gene expression are opposite to each other (Fold change: $\geq 2, \leq 0.5$; Normalized RC ( $\log 2)$ : $\geq 10$ ). (a)Ag-PVP/control vs $\mathrm{HP} /$ control vs Ag-PVP+HP/control, (b)Ag-PVP/control vs Hym176/control vs Ag-PVP+Hym176/control, (c)Ag-PVP/control vs HP/control vs Hym176/control, (d)Ag-PVP/control vs Ag-PVP+HP/control vs Ag-PVP+ Hym176/control, (e)Ag-PVP+HP/control vs HP/control vs Hym176/control vs Ag-PVP+ Hym176/control.

Microarray and DEG analyses were performed on the FC data for genes that affect morphogenesis and development of important organs (heart, eyes, nerves, etc.) during early embryonic development (Tables 3 and 4).

Table 3. Comparison of the number of genes with differences in expression level.

\begin{tabular}{lcccc}
\hline & & Total Genes & Up-Regulated & Down-Regulated \\
\hline N-Ag-PVP & vs. Control & $957(6.61 \%)$ & 377 & 580 \\
HP & vs. Control & $2686(18.56 \%)$ & 1066 & 1620 \\
N-Ag-PVP+HP & vs. Control & $928(6.41 \%)$ & 379 & 549 \\
Hym176 & vs. Control & $1229(8.49 \%)$ & 545 & 684 \\
N-Ag-PVP+Hym176 & vs. Control & $1284(8.87 \%)$ & 632 & 652 \\
N-Ag-PVP+HP & vs. HP & $2879(19.89 \%)$ & 1652 & 1227 \\
N-Ag-PVP+Hym176 & vs. Hym176 & $164(1.13 \%)$ & 112 & 52 \\
N-Ag-PVP+Hym176 & vs. N-Ag-PVP+HP & $353(2.44 \%)$ & 202 & 151 \\
N-Ag-PVP+HP & vs. N-Ag-PVP & $110(0.76 \%)$ & 49 & 61 \\
N-Ag-PVP+Hym176 & vs. N-Ag-PVP & $552(3.81 \%)$ & 332 & 220 \\
\hline
\end{tabular}

GO analyses revealed that a large number of genes associated with the N-Ag-PVP-exposed group are linked with epistatic interactions during morphogenesis and development. In particular, the GOs associated with morphogenesis via epistatic interactions were animal organ morphogenesis (GO:0009887), anatomical structure morphogenesis (GO:0009653), and developmental processes (GO:0032502). Therefore, gene mutations induced by N-Ag-PVP toxicity may directly cause abnormal appearance of exposed larvae. Moreover, some of the genes involved in morphogenesis and development are involved in abnormalities of important organs and other diseases. In addition to embryonic development, lmo7b, lum, sec23a, fn1b, zeb2b, and fxr1, which were found in various GOs, affect the heart [43], nearsightedness [44], skeletal morphogenesis [45,46], tissue regeneration [47,48] 
and signal transduction [49,50], thereby inducing weakness, mental retardation [51], and muscular atrophy [52].

Table 4. Genes showing toxicity reduction effects classified according to GO of morphogenesis.

\begin{tabular}{|c|c|c|c|c|c|c|}
\hline \multirow[b]{2}{*}{ Gene Description } & \multirow[b]{2}{*}{$\begin{array}{l}\text { Gene } \\
\text { Symbol }\end{array}$} & \multicolumn{5}{|c|}{ Regulation Profile and Ratio(Fold change) } \\
\hline & & $\begin{array}{l}\text { N-Ag-PVP } \\
\text { /Control }\end{array}$ & $\begin{array}{c}\text { HP } \\
\text { /Control }\end{array}$ & $\begin{array}{l}\text { N-Ag-PVP+HP } \\
\text { /Control }\end{array}$ & $\begin{array}{l}\text { Hym176 } \\
\text { /Control }\end{array}$ & $\begin{array}{c}\text { N-Ag-PVP } \\
\text { +Hym176 } \\
\text { /Control }\end{array}$ \\
\hline \multicolumn{7}{|c|}{ Heart morphogenesis (GO:0003007) } \\
\hline \multirow{3}{*}{$\begin{array}{l}\text { LIM domain } 7 \mathrm{~b} \\
\text { fibronectin } 1 \mathrm{~b} \\
\text { myosin binding protein } \mathrm{C} \text {, } \\
\text { cardiac }\end{array}$} & $1 \mathrm{mo} 7 \mathrm{~b}$ & 2.708 & 0.743 & 1.415 & 2.264 & 1.425 \\
\hline & fn1b & 2.179 & 1.643 & 1.723 & 3.874 & 5.859 \\
\hline & mybpc3 & 0.357 & 1.706 & 0.569 & 0.493 & 0.959 \\
\hline \multicolumn{7}{|c|}{ Fin morphogenesis (GO:0033334) } \\
\hline $\begin{array}{l}\text { Sec } 23 \text { homolog A, COPII coat } \\
\text { complex component }\end{array}$ & $\sec 23 a$ & 0.448 & 1.369 & 0.709 & 0.588 & 0.832 \\
\hline $\begin{array}{l}\text { procollagen-lysine, } \\
\text { 2-oxoglutarate 5-dioxygenase 1a }\end{array}$ & plod1a & 0.441 & 0.869 & 0.611 & 0.462 & 0.665 \\
\hline \multicolumn{7}{|c|}{ Embryonic organ morphogenesis (GO:0048562) } \\
\hline LIM domain $7 \mathrm{~b}$ & $1 \mathrm{mo} 7 \mathrm{~b}$ & 2.708 & 0.743 & 1.415 & 2.264 & 1.425 \\
\hline lumican & lum & 0.491 & 1.359 & 0.620 & 0.701 & 0.625 \\
\hline $\begin{array}{l}\text { Sec } 23 \text { homolog A, COPII coat } \\
\text { complex component }\end{array}$ & $\sec 23 a$ & 0.448 & 1.369 & 0.709 & 0.588 & 0.832 \\
\hline \multicolumn{7}{|c|}{ Eye morphogenesis (GO:0048592) } \\
\hline $\begin{array}{l}\text { intraflagellar transport } 80 \\
\text { homolog (Chlamydomonas) }\end{array}$ & ift 80 & 2.179 & 0.722 & 1.356 & 1.416 & 1.203 \\
\hline $\begin{array}{l}\text { tubulin, gamma complex } \\
\text { associated protein } 4\end{array}$ & tubgcp4 & 2.017 & 0.698 & 1.563 & 1.177 & 0.896 \\
\hline lumican & lum & 0.491 & 1.359 & 0.620 & 0.701 & 0.625 \\
\hline adiponectin receptor $1 \mathrm{~b}$ & adipor1b & 0.444 & 0.924 & 0.620 & 0.271 & 0.371 \\
\hline
\end{tabular}

Therefore, N-Ag-PVP and Hym176 aggregates, which are small, seemed to influence embryonic organ morphogenesis and development by passing through the embryonic CPCs and cell membrane. It has been reported that N-Ag-PVP, which penetrates the embryos through CPCs, is adsorbed onto the surface of cell membrane proteins, activating them [53]. This interaction may lead to immobilization of cell membrane proteins and up-regulation of GPCR-associated genes [54].

Analyses of the gene expression patterns of hatched larvae in the N-Ag-PVP-exposed group revealed an effect on genes related to tight junctions and the FOXO and MAPK signaling pathways (Figure 3a). Exposure to N-Ag-PVP increased the expression of major genes in the MAPK signaling pathway, thereby affecting cell proliferation and differentiation, and inducing inflammatory responses. The N-Ag-PVP exposure induced down-regulation of the cldna, cldnb, and oclua genes involved in intercellular signaling (Figure 3b). The HP-exposed group had similar regulation of the tight junction and MAPK signaling pathways to the control group. Moreover, Akt2l was down-regulated in all experimental groups compared with the control group, whereas foxo1a was up-regulated (Figure 3c). In addition, down-regulation of FOXO transcription factors, associated with homeostasis during environmental changes, stress, and inflammatory responses, is likely to impair blood glucose regulation by reducing glycolysis/gluconeogenesis, causing diabetes [55]. Furthermore, in the N-Ag-PVP-exposed group, up-regulation of mapk10 and mapk11 in the MAPK signaling pathway induced cell proliferation, cell differentiation, apoptosis, and inflammation, while down-regulation of tp53 prevented activation of the anticancer mechanism of p53, potentially leading to cancer (Figure 3d) [56].

$\mathrm{N}-\mathrm{Ag}$-PVP exposure up- or down-regulated genes involved in morphogenesis and development of important organs during embryonic development. N-Ag-PVP, N-Ag-PVP+HP, Hym176, and $\mathrm{N}-\mathrm{Ag}-\mathrm{PVP}+\mathrm{Hym} 176$, all of which were absorbed into the cell, affected multiple signaling pathways within the cell. Tight junctions regulate the passage of ions and molecules in the epithelial and endothelial cell pathways [57]. Claudin, a cell membrane protein that constitutes a tight junction, determines intercellular ion selectivity [58]. However, N-Ag-PVP down-regulated claudin expression 
and decreased intercellular signal transduction. In addition, when the cell membrane proteins lose their fluidity, cellular structural integrity and signal transduction pathways may be impacted. In the absence of growth factor signaling or activation of Akt in the FOXO signaling pathway, FOXO up-regulates the target genes involved in stress resistance, metabolism, and apoptosis, which may impact lifespan and tumor growth [59]. The FOXO transcription factor remains inactive under normal conditions, but is activated to maintain homeostasis in response to environmental changes and stress; FOXO also inhibits insulin and growth factor signals [60]. In addition, genes in the MAPK signaling pathway regulate cell proliferation, differentiation, survival, inflammation, and apoptosis through stimulation of growth factors, cytokines, and stress and therefore play an important role in intracellular signal transduction [61].

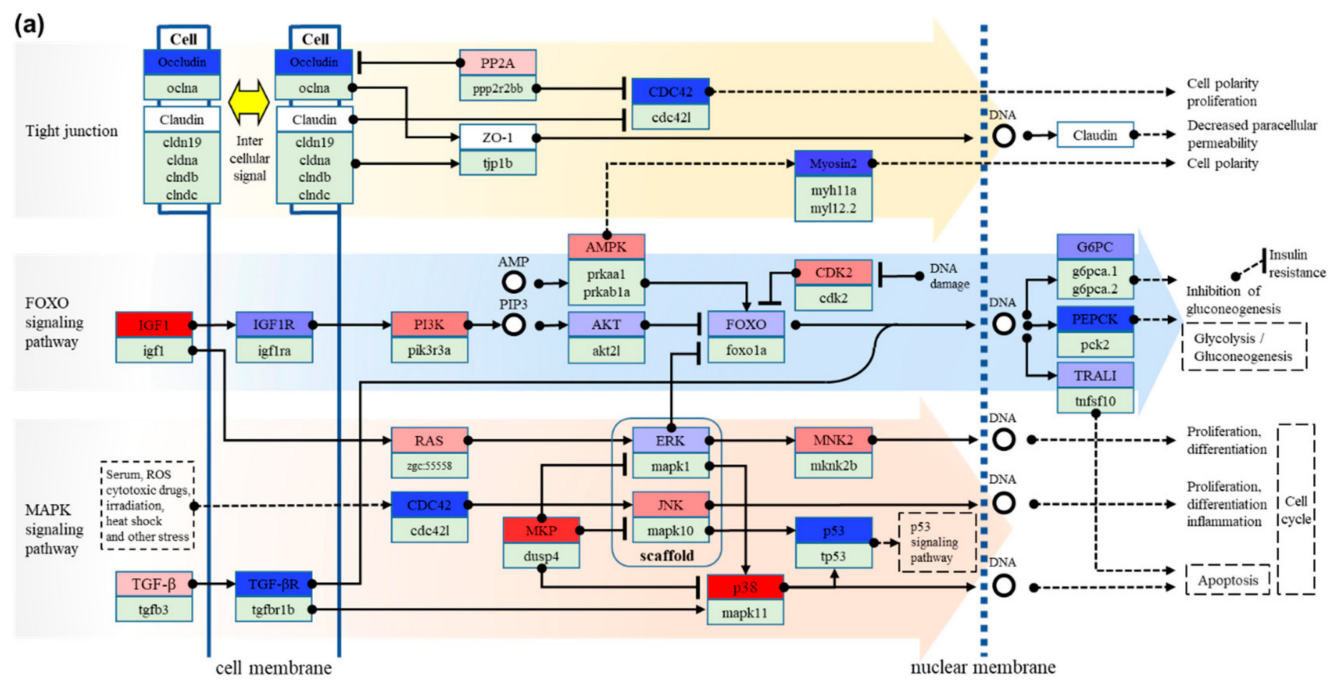

(b)

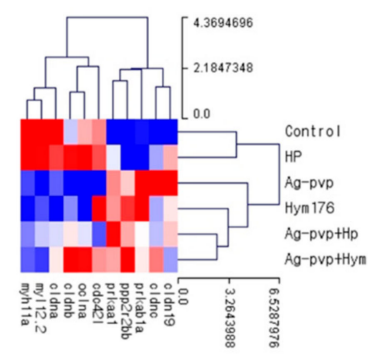

(c)

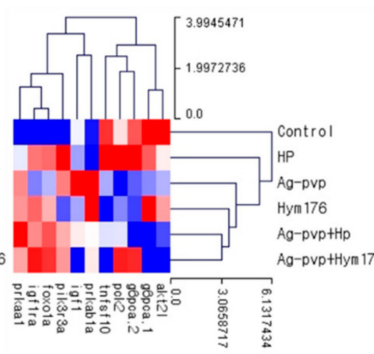

(d)

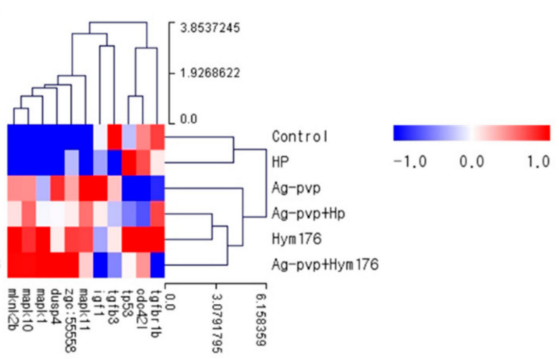

Figure 3. (a) Pathway for effects on cell cycle regulation and intercellular signaling in zebrafish exposed to N-Ag-PVP; and heat maps of the (b) tight junction, (c) fork headbox O (FOXO) signaling pathway, and (d) mitogen-activated protein kinases (MAPK) signal pathway. (b-d) show the z-scores based on the average of each expressed gene.

In the control and HP-exposed groups, similar expression patterns were observed for GPCRs, but up-regulation of amines and peptides of GPCRs and receptors for luteinizing hormone (LH) and thyroid stimulating hormone (TSH) were evident in the N-Ag-PVP-exposed group (Figure 4a). The control and HP-exposed groups had very similar expression patterns, except for the cga gene, where opposing results were obtained for the two groups (Figure 4b). GPCRs constitute a large proportion of the cell-surface receptors and regulate many cell functions, including cell proliferation, survival, and motility, and play a key role in tumor growth, angiogenesis, and metastasis [62]. The up- or down-regulation of GPCR-associated genes may inhibit receptor-mediated intercellular signaling $[63,64]$. 
(a) G protein-coupled receptors (GPCRs)

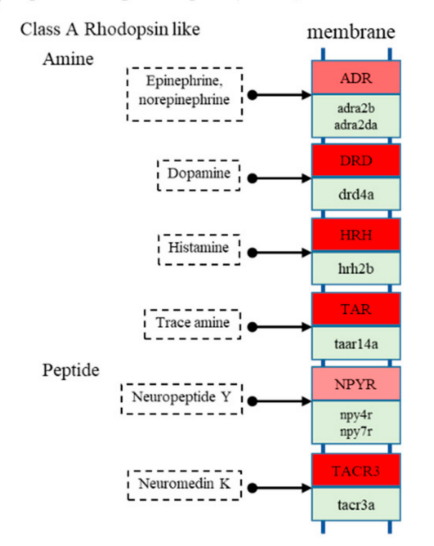

(b)

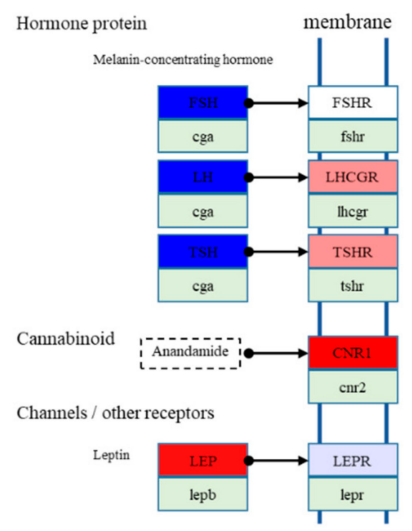

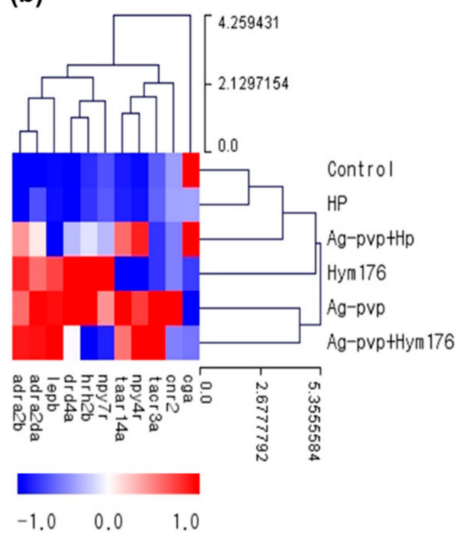

Figure 4. (a) Effects of N-Ag-PVP exposure on G-protein-coupled receptor (GPCR) gene expression in zebrafish larvae and (b) heatmap of GPCRs by z-score. N-Ag-PVP stimulated up-regulation of several GPCR genes. The z-score is based on the average of each expressed gene.

The FC and qRT-PCR for the major genes in the intracellular signaling pathways were compared and shown in Figure 5. The Zgc:55558 was similarly expressed in all experimental groups, except for a 2.25- and 2.64-fold increase in the Hym176- and N-Ag-PVP+Hym176-exposed groups, respectively. In addition, the expression of Mapk10 increased more than two-fold in the N-Ag-PVP- and Hym176-exposed groups, while that of Mapk11 increased more than two-fold in the N-Ag-PVP-, Hym176-, and $\mathrm{N}-\mathrm{Ag}-\mathrm{PVP}+\mathrm{Hym} 176$-exposed groups. The expression of Cdc421 was not significantly among the experimental groups.
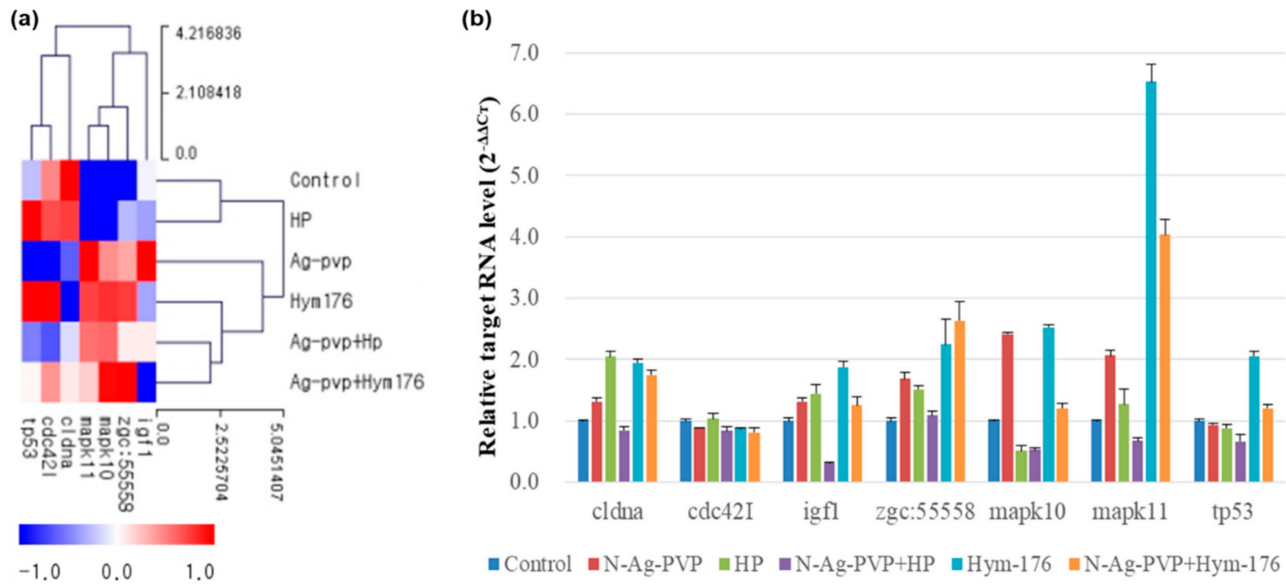

Figure 5. Comparison of expected and measured expression of key genes in zebrafish larvae exposed to N-Ag-PVP, HP, N-Ag-PVP+HP, Hym176, or N-Ag-PVP+Hym176. (a) Gene expression level by z-score and $(\mathrm{b})$ relative target RNA level $\left(2^{-\Delta \Delta \mathrm{Ct}}\right)$. The z-score is based on the average of each expressed gene $\left(\Delta \mathrm{Ct}=\right.$ Target $\mathrm{Ct}-\mathrm{actb} 2 \mathrm{Ct}, \Delta \Delta \mathrm{Ct}=$ Target Sample $\Delta \mathrm{Ct}-$ control Sample $\Delta \mathrm{Ct}, 2^{-\Delta \Delta \mathrm{Ct}}=$ Normalized gene amount of target group relative to target gene amount of control group).

Finally, N-Ag-PVP exposure caused an abnormal appearance in the zebrafish embryos, but co-incubation with HP or Hym176 tended to reduce the toxicity by forming aggregates with N-Ag-PVP. Therefore, additional studies investigating the formation of aggregates with nanomaterials are needed. In addition, further research addressing the genetic effects of nanomaterials is needed. It is expected that proteins and peptides derived from Hydra may be used as bio-derived materials for the capture and treatment of nanomaterials released into ecosystems. 


\section{Conclusions}

We investigated and attempted to reduce the toxicity of N-Ag-PVP using the bioderived materials HP and Hym176. N-Ag-PVP and HP showed changes in surface charge and particle size after bonding, and N-Ag-PVP+HP formed agglomerates of $200 \mathrm{~nm}$ or more by electrostatic bonding. The N-Ag-PVP exposed group showed a low hatching rate $(41.7 \pm 2.9 \%)$ and high abnormality rate $(27.8 \pm 4.8 \%)$, including various forms such as inflammation, edema, and tail and kidney morphology in hatched fry. The group exposed to HP showed aggregated N-Ag-PVP to reduce toxicity. However, $\mathrm{N}-\mathrm{Ag}-\mathrm{PVP}+\mathrm{Hym} 176$ exposure group showed a high rate of abnormality $(39.4 \pm 5.2 \%)$. In the results of the mRNA seq analysis, the gene expression pattern of the HP exposure group was different from those of the N-Ag-PVP, N-Ag-PVP+HP, Hym176, and N-Ag-PVP+Hym176 exposed groups. N-Ag-PVP has the potential to be directly responsible for abnormalities during the early developmental stage of the embryo, with variations in morphogenesis and development of key organs (heart, eyes, nerves, etc.). However, there was no genetic toxicity in the HP exposure group. HP is not toxic and has a tendency to reduce the ecotoxic and genotoxic effects of N-Ag-PVP. As a result, HP, a natural substance, shows potential as a candidate material for reducing the toxicity of nanomaterials.

Supplementary Materials: The following are available online at http://www.mdpi.com/2079-4991/9/9/1210/s1, Figure S1: A, FE-SEM analysis of (a) N-Ag-PVP, (b) HP and (c) N-Ag-PVP+HP. * Red wedge is N-Ag-PVP; B, XRD patterns of (a) N-Ag-PVP and (b) N-Ag-PVP+HP; C, High resolution-raman analysis of N-Ag-PVP, $\mathrm{N}-\mathrm{Ag}-\mathrm{PVP}+\mathrm{HP}$ and HP. Figure S2: Condition of embryos (1.5 hpf) and media immediately after exposure about (a) Control, (b) N-Ag-PVP, (c) HP, (d) N-Ag-PVP+HP, (e) Hym176 and (f) N-Ag-PVP+Hym176(c, chorion). Figure S3: The effects of the N-Ag-PVP with Hydra materials (HP, Hym 176) and pure N-Ag-PVP on the development of zebrafish. Embryos were exposed to (a) Control, (b) N-Ag-PVP(1 mg/L), (c) HP(4 mg/L), (d) N-Ag-PVP+HP(1 or $4 \mathrm{mg} / \mathrm{L}),(\mathrm{e}) \mathrm{Hym} 176(4 \mathrm{mg} / \mathrm{L})$ and (f) N-Ag-PVP+Hym176(1 or $4 \mathrm{mg} / \mathrm{L})$. These images show exposed zebrafish at 72 hpf. Abbreviations: i, inflammation; t, tail; $n$, notochord; e, edema; k, kidney; y, yolk sac., Figure S4: Hierarchical clustering analyzed by z-score of differentially expressed genes in zebrafish larva exposed to each experimental group (Fold change: $\geq 2, \leq 0.5$; Normalized RC $(\log 2)$ : $\geq 5$ ). The $z$-score is based on the mean of each expressed gene.

Author Contributions: S.S.K. performed nanomaterial characterization, toxicity testing and gene analysis. J.A.L. contributed to hydra material preparation and nanomaterial characterization analysis. M.-K.Y. is designed the experiments and wrote the paper.

Funding: Funding for this research was received from the Basic Science Research Program of the National Research Foundation of Korea (NRF), which is funded by the Ministry of Education (NRF-2016R1A2B4016442 and NRF-2019R1A2C1004616).

Conflicts of Interest: The authors declare no conflict of interest.

\section{References}

1. Auffan, M.; Rose, J.; Bottero, J.Y.; Lowry, G.V.; Jolivet, J.P.; Wiesner, M.R. Towards a definition of inorganic nanoparticles from an environmental, health and safety perspective. Nat. Nanotechnol. 2009, 4, 634-641. [CrossRef] [PubMed]

2. Durán, N.; Durán, M.; de Jesus, M.B.; Seabra, A.B.; Fávaro, W.J.; Nakazato, G. Silver nanoparticles: A new view on mechanistic aspects on antimicrobial activity. Nanomed. Nanotechnol. Biol. Med. 2016, 12, 789-799.

3. Blaser, S.A.; Scheringer, M.; MacLeod, M.; Hungerbühler, K. Estimation of cumulative aquatic exposure and risk due to silver: Contribution of nano-functionalized plastics and textiles. Sci. Total Environ. 2008, 390, 396-409. [CrossRef] [PubMed]

4. Benn, T.M.; Westerhoff, P. Nanoparticle silver released into water from commercially available sock fabrics. Environ. Sci. Technol. 2008, 42, 4133-4139. [CrossRef] [PubMed]

5. Chaudhry, Q.; Scotter, M.; Blackburn, J.; Ross, B.; Boxall, A.; Castle, L.; Aitken, R.; Watkins, R. Applications and implications of nanotechnologies for the food sector. Food Addit. Contam. 2008, 25, 241-258. [CrossRef]

6. Chen, X.; Schluesener, H.J. Nanosilver: A nanoproduct in medical application. Toxicol. Lett. 2008, 176, 1-12. [CrossRef]

7. Yeo, M.K.; Kang, M.S. Effects of nanometer sized silver materials on biological toxicity during zebrafish embryogenesis. Bull. Korean Chem. Soc. 2008, 29, 1179-1184. 
8. Park, H.G.; Yeo, M.K. Toxic effects against bacteria of silver nanocolloids and silver nanotubes in the presence of hydra cells. Mol. Cell. Toxicol. 2017, 13, 37-47.

9. Wijnhoven, S.W.P.; Peijnenburg, W.J.G.M.; Herberts, C.A.; Hagens, W.I.; Oomen, A.G.; Heugens, E.H.W.; Roszek, B.; Bisschops, J.; Gosens, I.; van de Meent, D.; et al. Nano-silver-a review of available data and knowledge gaps in human and environmental risk assessment. Nanotoxicology 2009, 3, 109-138. [CrossRef]

10. Gottschalk, F.; Sun, T.; Nowack, B. Environmental concentrations of engineered nanomaterials: Review of modeling and analytical studies. Environ. Pollut. 2013, 181, 287-300. [CrossRef]

11. Klaine, S.J.; Koelmans, A.A.; Horne, N.; Carley, S.; Handy, R.D.; Kapustka, L.; Nowack, B.; von der Kammer, F. Paradigms to assess the environmental impact of manufactured nanomaterials. Environ. Toxicol. Chem. 2012, 31, 3-14. [CrossRef]

12. Westerhoff, P.K.; Kiser, M.A.; Hristovski, K. Nanomaterial removal and transformation during biological wastewater treatment. Environ. Eng. Sci. 2013, 30, 109-117.

13. Meyer, D.E.; Curran, M.A.; Gonzalez, M.A. An examination of existing data for the industrial manufacture and use of nanocomponents and their role in the life cycle impact of nanoproducts. Environ. Sci Technol. 2009, 43, 1256-1263. [CrossRef] [PubMed]

14. Lombi, E.; Donner, E.; Taheri, S.; Tavakkoli, E.; Jämting, Å.K.; McClure, S.; Naidu, R.; Miller, B.W.; Scheckel, K.G.; Vasilev, K. Transformation of four silver/silver chloride nanoparticles during anaerobic treatment of wastewater and post-processing of sewage sludge. Environ. Pollut. 2013, 176, 193-197. [CrossRef] [PubMed]

15. Wang, L.S.; Wei, D.B.; Wei, J.; Hu, H.Y. Screening and estimating of toxicity formation with photobacterium bioassay during chlorine disinfection of wastewater. J. Hazard. Mater. 2007, 141, 289-294. [CrossRef] [PubMed]

16. Park, H.G.; Yeo, M.K. Comparison of gene expression patterns from zebrafish embryos between pure silver nanomaterial and mixed silver nanomaterial containing cells of Hydra magnipapillata. Mol. Cell. Toxicol. 2015, 11, 307-314. [CrossRef]

17. Yeo, M.K.; Yoon, J.W. Comparison of the effects of nano-silver antibacterial coatings and silver ions on zebrafish embryogenesis. Mol. Cell. Toxicol. 2009, 5, 23-31.

18. Bosch, T.C. Understanding complex host-microbe interactions in Hydra. Gut Microbes 2012, 3, 345-351. [CrossRef]

19. Sarras, M.P., Jr.; Deutzmann, R. Hydra and Niccolo Paganini (1782-1840)—two peas in a pod? The molecular basis of extracellular matrix structure in the invertebrate, Hydra. BioEssays 2001, 23, 716-724. [CrossRef]

20. Fujisawa, T. Hydra regeneration and epitheliopeptides. Dev. Dyn. 2003, 226, 182-189. [CrossRef]

21. Mergaert, P. Role of Antimicrobial Peptides in Controlling Symbiotic Bacterial Populations. Nat. Prod. Rep. 2018, 35, 336-356. [CrossRef] [PubMed]

22. Fujisawa, T. Hydra peptide project 1993-2007. Dev. Growth Differ. 2008, 50, S257-S268. [CrossRef] [PubMed]

23. Westerfield, M. The Zebrafish Book. A Guide for the Laboratory Use of Zebrafish (Danio rerio), 4th ed.; University of Oregon Press: Eugene, OR, USA, 2000.

24. Paulson, H.L.; Perez, M.K.; Trottier, Y.; Trojanowski, J.Q.; Subramony, S.H.; Das, S.S.; Vig, P.; Mandel, J.L.; Fischbeck, K.H.; Pittman, R.N. Intranuclear inclusions of expanded polyglutamine protein in spinocerebellar ataxia type 3. Neuron 1997, 19, 333-344. [CrossRef]

25. Yum, S.; Woo, S.; Lee, A.; Won, H.; Kim, J. Hydra, a candidate for an alternative model in environmental genomics. Mol. Cell. Toxicol. 2014, 10, 339-346. [CrossRef]

26. Kimmel, C.B.; Ballard, W.W.; Kimmel, S.R.; Ullmann, B.; Schilling, T.F. Stages of embryonic development of the zebrafish. Dev. Dyn. 1995, 203, 253-310.

27. Li, X.; Song, G.; Zhao, Y.; Zhao, F.; Liu, C.; Liu, D.; Li, Q.; Cui, Z. Claudin7b is required for the formation and function of inner ear in zebrafish. J. Cell. Physiol. 2018, 233, 3195-3206.

28. Wakayama, Y.; Fukuhara, S.; Ando, K.; Matsuda, M.; Mochizuki, N. Cdc42 mediates Bmp-induced sprouting angiogenesis through Fmnl3-driven assembly of endothelial filopodia in zebrafish. Dev. Cell 2015, 32, 109-122. [CrossRef]

29. Eivers, E.; Mccarthy, K.; Glynn, C.; Nolan, C.M.; Byrnes, L. Insulin-like growth factor (IGF) signalling is required for early dorso-anterior development of the zebrafish embryo. Int. J. Dev. Biol. 2004, 48, 1131-1140. [CrossRef] 
30. Park, H.; Kim, J.; Chang, K.; Lee, C.; Eom, I.; Kim, P.; Nam, D.; Yeo, M. Trophic transfer of citrate, PVP coated silver nanomaterials, and silver ions in a paddy microcosm. Environ. Pollut. 2018, 235, 435-445. [CrossRef]

31. Meloche, S.; Pouysségur, J. The ERK1/2 mitogen-activated protein kinase pathway as a master regulator of the G1-to S-phase transition. Oncogene 2007, 26, 3227. [CrossRef]

32. Gharibshahi, L.; Saion, E.; Gharibshahi, E.; Shaari, A.H.; Matori, K.A. Influence of Poly (vinylpyrrolidone) concentration on properties of silver nanoparticles manufactured by modified thermal treatment method. PLoS ONE 2017, 12, e0186094. [CrossRef] [PubMed]

33. Naja, G.; Bouvrette, P.; Hrapovic, S.; Luong, J.H. Raman-based detection of bacteria using silver nanoparticles conjugated with antibodies. Analyst 2007, 132, 679-686. [CrossRef] [PubMed]

34. Mao, H.; Feng, J.; Ma, X.; Wu, C.; Zhao, X. One-dimensional silver nanowires synthesized by self-seeding polyol process. J. Nanopart. Res. 2012, 14, 887. [CrossRef]

35. Lowry, G.V.; Gregory, K.B.; Apte, S.C.; Lead, J.R. Transformations of nanomaterials in the environment. Environ. Sci. Technol. 2012, 46, 6893-6899. [CrossRef]

36. Levard, C.; Hotze, E.M.; Lowry, G.V.; Brown, G.E., Jr. Environmental transformations of silver nanoparticles: Impact on stability and toxicity. Environ. Sci. Technol. 2012, 46, 6900-6914. [PubMed]

37. McShan, D.; Ray, P.C.; Yu, H. Molecular toxicity mechanism of nanosilver. J. Food Drug Anal. 2014, 22, 116-127. [CrossRef] [PubMed]

38. Morones, J.R.; Elechiguerra, J.L.; Camacho, A.; Holt, K.; Kouri, J.B.; Ramirez, J.T.; Yacaman, M.J. The bactericidal effect of silver nanoparticles. Nanotechnology 2005, 16, 2346. [CrossRef]

39. Liu, J.; Hurt, R.H. Ion release kinetics and particle persistence in aqueous nano-silver colloids. Environ. Sci. Technol. 2010, 44, 2169-2175. [CrossRef]

40. Berghmans, S.; Butler, P.; Goldsmith, P.; Waldron, G.; Gardner, I.; Golder, Z.; Richards, F.M.; Kimber, G.; Roach, A.; Alderton, W.; et al. Zebrafish based assays for the assessment of cardiac, visual and gut function-potential safety screens for early drug discovery. J. Pharmacol. Toxicol. Methods 2008, 58, 59-68. [CrossRef]

41. Lee, K.J.; Nallathamby, P.D.; Browning, L.M.; Osgood, C.J.; Nancy, X.H. In vivo imaging of transport and biocompatibility of single silver nanoparticles in early development of zebrafish embryos. ACS Nano 2007, 1, 133-143. [CrossRef]

42. Anselmo, A.C.; Zhang, M.; Kumar, S.; Vogus, D.R.; Menegatti, S.; Helgeson, M.E.; Mitragotri, S. Elasticity of nanoparticles influences their blood circulation, phagocytosis, endocytosis, and targeting. ACS Nano 2015, 9, 3169-3177. [CrossRef] [PubMed]

43. Metreveli, G.; Frombold, B.; Seitz, F.; Grun, A.; Philippe, A.; Rosenfeldt, R.R.; Bundschuh, M.; Schulz, R.; Manz, W.; Schaumann, G.E. Impact of chemical composition of ecotoxicological test media on the stability and aggregation status of silver nanoparticles. Environ. Sci. Nano 2016, 3, 418-433. [CrossRef]

44. Ott, E.B.; van den Akker, N.M.; Sakalis, P.A.; Gittenberger-de Groot, A.C.; Te Velthuis, A.J.; Bagowski, C.P. The lim domain only protein 7 is important in zebrafish heart development. Dev. Dyn. Off. Publ. Am. Assoc. Anat. 2008, 237, 3940-3952. [CrossRef] [PubMed]

45. Yeh, L.K.; Liu, C.Y.; Kao, W.W.W.Y.; Huang, C.J.; Hu, F.R.; Chien, C.L.; Wang, I.J. Knockdown of zebrafish lumican gene (zlum) causes scleral thinning and increased size of scleral coats. J. Biol. Chem. 2010, 285, 28141-28155. [CrossRef] [PubMed]

46. Boyadjiev, S.A.; Fromme, J.C.; Ben, J.; Chong, S.S.; Nauta, C.; Hur, D.J.; Zhang, G.; Hamamoto, S.; Schekman, R.; Ravazzola, M.; et al. Cranio-lenticulo-sutural dysplasia is caused by a SEC23A mutation leading to abnormal endoplasmic-reticulum-to-Golgi trafficking. Nat. Genet. 2006, 38, 1192-1197. [CrossRef] [PubMed]

47. Cox, N.J.; Unlu, G.; Bisnett, B.J.; Meister, T.R.; Condon, B.M.; Luo, P.M.; Smith, T.J.; Hanna, M.; Chhetri, A.; Soderblom, E.J.; et al. Dynamic glycosylation governs the vertebrate COPII protein trafficking pathway. Biochemistry 2017, 57, 91-107. [CrossRef] [PubMed]

48. Sun, L.; Zou, Z.; Collodi, P.; Xu, F.; Xu, X.; Zhao, Q. Identification and characterization of a second fibronectin gene in zebrafish. Matrix Biol. 2005, 24, 69-77. [CrossRef]

49. Shibata, E.; Ando, K.; Murase, E.; Kawakami, A. Heterogeneous fates and dynamic rearrangement of regenerative epidermis-derived cells during zebrafish fin regeneration. Development 2018, 145, 162016. [CrossRef] 
50. Ghoumid, J.; Drevillon, L.; Alavi-Naini, S.M.; Bondurand, N.; Rio, M.; Briand-Suleau, A.; Nasser, M.; Goodwin, L.; Raymond, P.; Yanicostas, C.; et al. ZEB2 zinc-finger missense mutations lead to hypomorphic alleles and a mild Mowat-Wilson syndrome. Hum. Mol. Genet. 2013, 22, 2652-2661. [CrossRef]

51. Taibi, A.; Mandavawala, K.P.; Noel, J.; Okoye, E.V.; Milano, C.R.; Martin, B.L.; Sirotkin, H.I. Zebrafish churchill regulates developmental gene expression and cell migration. Dev. Dyn. 2013, 242, 614-621. [CrossRef]

52. Say, E.; Tay, H.G.; Zhao, Z.S.; Baskaran, Y.; Li, R.; Lim, L.; Manser, E. A functional requirement for PAK1 binding to the KH (2) domain of the fragile X protein-related FXR1. Mol. Cell. 2010, 38, 236-249. [CrossRef] [PubMed]

53. Van't Padje, S.; Chaudhry, B.; Severijnen, L.A.; van der Linde, H.C.; Mientjes, E.J.; Oostra, B.A.; Willemsen, R. Reduction in fragile $\mathrm{X}$ related 1 protein causes cardiomyopathy and muscular dystrophy in zebrafish. J. Exp. Biol. 2009, 212, 2564-2570. [CrossRef] [PubMed]

54. Lynch, I.; Dawson, K.A. Protein-nanoparticle interactions. Nano Today 2008, 3, 40-47. [CrossRef]

55. Fruh, V.; IJzerman, A.P.; Siegal, G. How to catch a membrane protein in action: A review of functional membrane protein immobilization strategies and their applications. Chem. Rev. 2010, 111, 640-656. [CrossRef] [PubMed]

56. Chatzopoulou, A.; Heijmans, J.P.; Burgerhout, E.; Oskam, N.; Spaink, H.P.; Meijer, A.H.; Schaaf, M.J. Glucocorticoid-induced attenuation of the inflammatory response in zebrafish. Endocrinology 2016, 157, 2772-2784. [CrossRef] [PubMed]

57. AshaRani, P.V.; Sethu, S.; Lim, H.K.; Balaji, G.; Valiyaveettil, S.; Hande, M.P. Differential regulation of intracellular factors mediating cell cycle, DNA repair and inflammation following exposure to silver nanoparticles in human cells. Genome Integr. 2012, 3, 2. [CrossRef]

58. Gonzalez-Mariscal, L.; Tapia, R.; Chamorro, D. Crosstalk of tight junction components with signaling pathways. Biochim. Et Biophys. Acta (Bba)-Biomembr. 2008, 1778, 729-756. [CrossRef]

59. Simon, D.B.; Lu, Y.; Choate, K.A.; Velazquez, H.; Al-Sabban, E.; Praga, M.; Casari, G.; Bettinelli, A.; Colussi, G.; Rodriguez-Soriano, J.; et al. Paracellin-1, a renal tight junction protein required for paracellular $\mathrm{Mg}^{+}$ resorption. Science 1999, 285, 103-106.

60. Calnan, D.R.; Brunet, A. The foxo code. Oncogene 2008, 27, 2276. [CrossRef]

61. Eijkelenboom, A.; Burgering, B.M.T. FOXOs: Signalling integrators for homeostasis maintenance. Nat. Rev. Mol. Cell Biol. 2013, 14, 83. [CrossRef]

62. Raman, M.; Chen, W.; Cobb, M.H. Differential regulation and properties of MAPKs. Oncogene 2007, $26,3100$. [CrossRef] [PubMed]

63. Dorsam, R.T.; Gutkind, J.S. G-protein-coupled receptors and cancer. Nat. Rev. Cancer 2007, 7, 79. [CrossRef] [PubMed]

64. Stoy, H.; Gurevich, V.V. How genetic errors in GPCRs affect their function: Possible therapeutic strategies. Genes Dis. 2015, 2, 108-132. [CrossRef] [PubMed]

(C) 2019 by the authors. Licensee MDPI, Basel, Switzerland. This article is an open access article distributed under the terms and conditions of the Creative Commons Attribution (CC BY) license (http://creativecommons.org/licenses/by/4.0/). 